\title{
Immediate Nail Bed Graft on Exposed Distal Phalanx in Fingertip Injury
}

\author{
Jinha Park (D), Si Young Roh (D) \\ Department of Plastic and Reconstructive Surgery, Gwangmyeong Sungae Hospital, Gwangmyeong, Korea
}

\begin{abstract}
Fingertip injuries with nail bed defects have traditionally been covered with full- or split-thickness nail bed grafts. However, it was widely understood, without sufficient evidence, that graft take is difficult if the nail bed is grafted directly on the distal phalanx. This study reports two successful cases of nail bed graft on sterile matrix defects with exposed bare cortical bone. Two patients suffered a crush injury on their fingers. While there was no fracture, the distal phalanx was exposed with a nailbed defect. As the defect was too large for primary closure and too small for flap coverage, a sterile matrix nailbed graft was performed using the ipsilateral big toe. In both cases, damaged nails have grown fully, identical to the contralateral finger with smooth and flat regrowth of the nail and adherence of the growing nail. Both outcomes were graded as excellent according to Zook's criteria. No major complication was found except for a minor ingrown nail on donor site in both cases. Even if there is a nail bed defect with exposure of cortical bone, successful nail reconstruction could be obtained through immediate nailbed graft on the exposed distal phalanx.
\end{abstract}

Keywords: Nail bed; Tissue graft; Fingertip

\section{서 론}

일상생활이나 산업 현장에서 자주 발생하는 수지 첨부의 손상에서 조갑상 결손이 동반된 경 우는 손톱의 발육 부전이나 변형을 초래한다[1]. 절단부가 없거나 결손이 심한 조갑 조직의 손 상에서 골 노출이 없다면 조갑상 이식술을 주로 시행해 왔다. 하지만 골 노출이 동반된 경우에 는 조갑상 이식이 생착할 혈류가 풍부한 바닥이 없기에 이식의 생존율이 낮을 것으로 생각되어 조갑상 이식술보다는 이차 유합을 통한상처의 자연적 치유나 국소 피판술을 주로 시행해왔다. 그러나 노출된 원위지골 위로 직접 조갑상 이식술을 시행을 할 때, 생착되지 않는다는 명확한 근거가 기존에 부족하였다. 이에 본 연구에서는 원위지골의 노출이 있는 무균 기질(sterile matrix)의 결손에 즉시 조갑상 이식술을 시행한 두 가지 증례에 대해 보고하려 한다. 본 연구에서 는 두 명의 환자에게 연구 동의서를 취득하였으며 이는 헬싱키 선언의 원칙에 따라 수행되었다.

\section{증 례}

\section{증례 1}

7세 남아가 문에 찧어져 수상하여 우측 소지의 압궤 손상으로 내원하였다. 원위지골의 골절은 없었으나, 무균 기질의 $1 \times 0.5 \mathrm{~cm}^{2}$ 의 결손과 함께 원위지골이 $5 \mathrm{~mm}$ 가량 노출되어 있었다(Fig. 1). 무균 기질의 결손과 원위지골의 노출은 일차 봉합을 하기에는 결손의 크기가 컸으며, 피판술 을 시행하기에는 크기가작은상태였다.

결손 주변의 바닥은 비교적 깨끗하였고 혈류의 공급이 원활한 것으로 확인되어, 노출된 원 위지골의 골막 위로 변연절제를 시행한 뒤, 피가 나는 것을 확인하여 원위지골의 생존을 확인 하였다. 동측 족부의 무지에서 부분층 두께로 조갑상의 무균 기질을 떼어내어 우측 소지의 결
Case Report

Received: September 18, 2020

Revised: September 29, 2020

Accepted: October 1, 2020

\section{Corresponding author:}

Si Young Roh, M.D. Ph.D.

Department of Plastic and Reconstructive Surgery, Gwangmyeong Sungae Hospital, 36 Digital-ro, Gwangmyeong 14241, Korea Tel: +82-2-2680-7238

Fax: +82-2-2680-7755

E-mail: psczero@gmail.com

This is an Open Access article distributed under the terms of the Creative Commons Attribution Non-Commercial License (https://creativecommons.org/licenses/by-nc/4.0/) which permits unrestricted non-commercial use, distribution, and reproduction in any medium, provided the original work is properly cited.

C) 2020 Korean Wound Management Society 

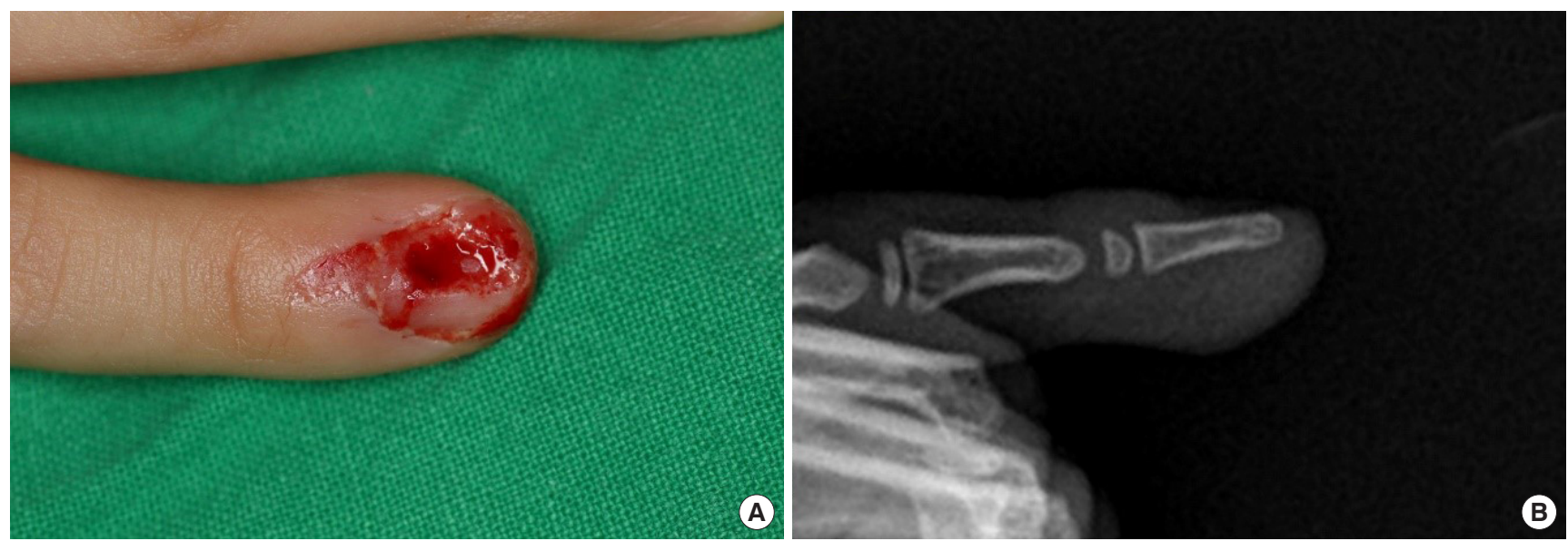

Fig. 1. Preoperative findings (case 1). (A) A 7-year-old patient presented with a defect in the sterile matrix and about 5 mm exposure of distal phalanx on the right little finger. The amputee was absent. (B) No fracture was seen, but exposed distal phalanx was found in X-ray.
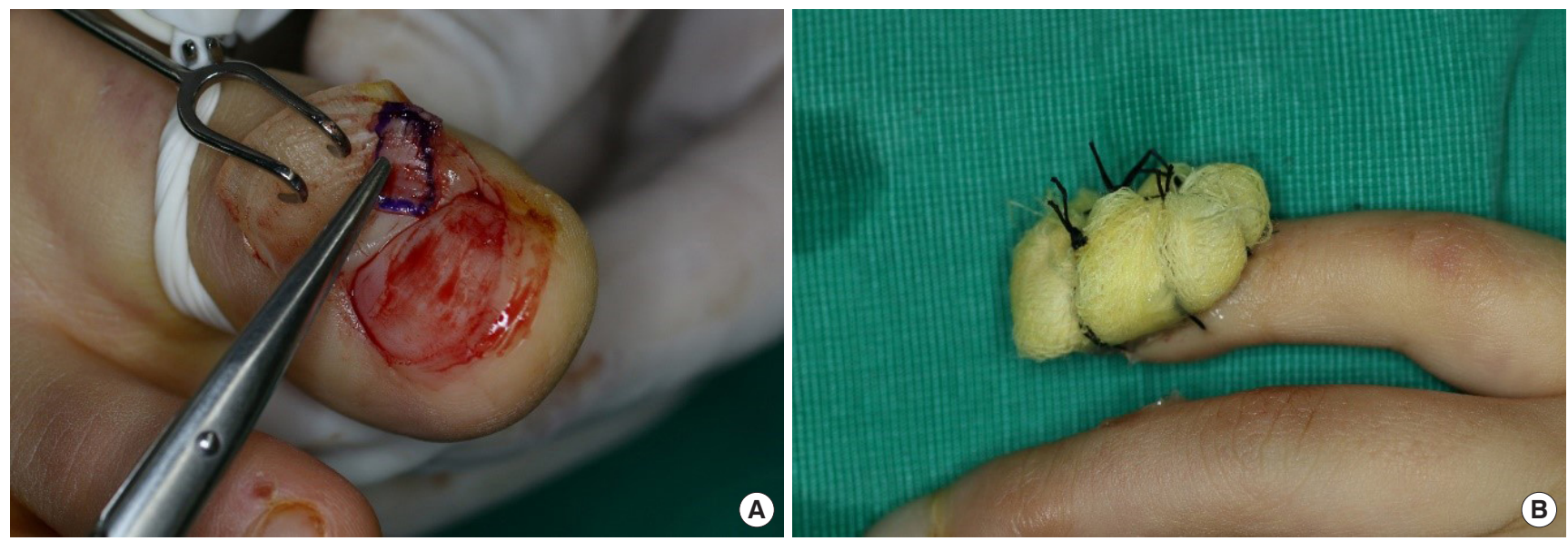

Fig. 2. Intraoperative findings (case 1). (A) A sterile matrix was taken from the ipsilateral big toe in the same shape as the defect. (B) The grafted sterile matrix was sutured on the defect according to the direction. Tie-over dressing was performed over the graft.
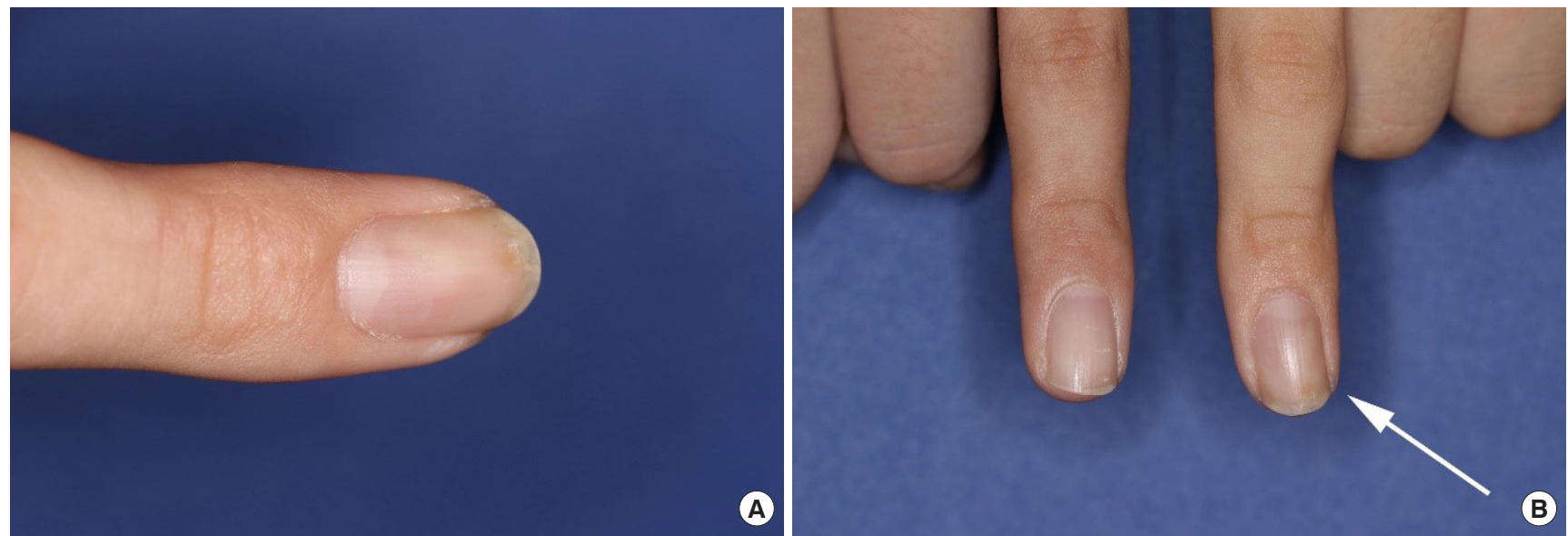

Fig. 3. Follow-up photographs (case 1). (A) Fifty-four months after the surgery, the shape of the nail was excellent according to Zook's criteria. (B) There was no difference between the operated nail (arrow) compared with the nail on the other hand. 

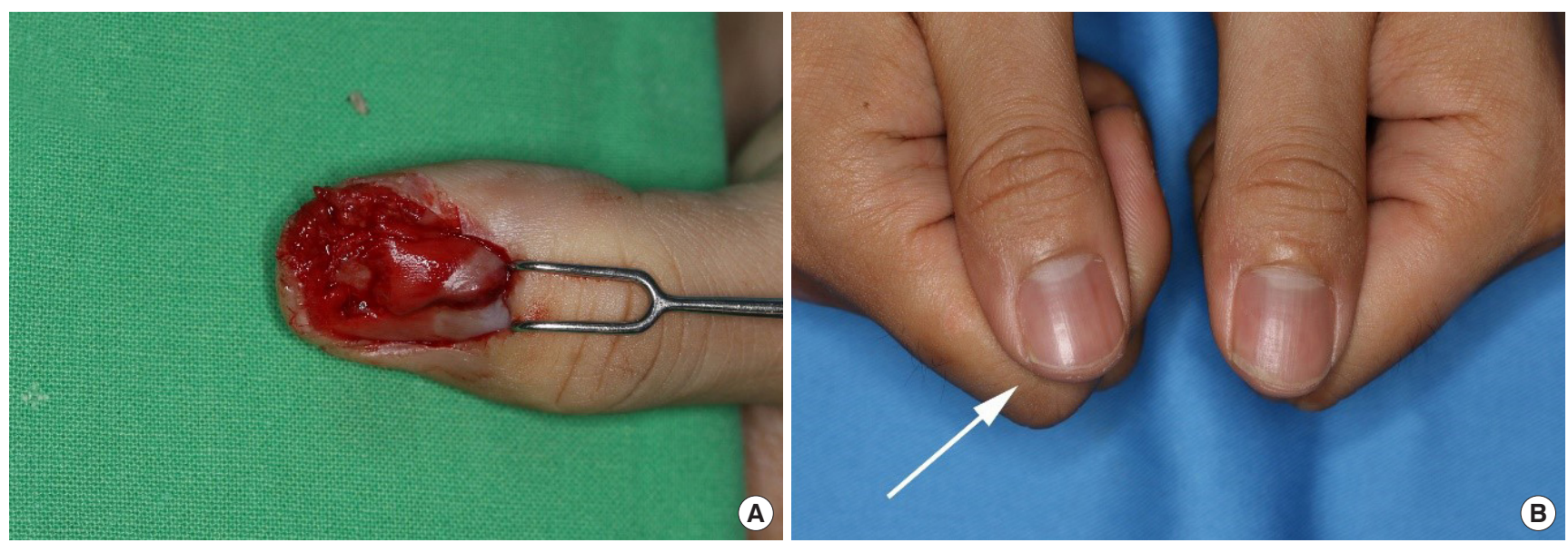

Fig. 4. Preoperative finding and follow-up photograph (case 2). (A) A 24-year-old patient presented with a defect in the sterile matrix and exposure of distal phalanx. (B) Eighteen months after surgery, there was no difference between the operated nail (arrow) and the nail of the other hand.

손 부위에 위치시킨 뒤 Vicryl \#6-0로 단순 봉합하였고, 조근에 기존 손톱을 삽입한 뒤 이식편 위로 기존의 손톱을 nylon \#5-0로 고정시켰 다. 이식편의 고정을 위하여 이식편 위로 봉합 고정 드레싱(tie-over dressing)을 시행하였다(Fig. 2). 봉합 고정은 수술 후 7일째에 제거하 여 이식편이 생착된 것을 확인하였다.

수술 후 3 주째부터 환자의 손톱이 지라는 것을 확인하였고, 이는 모양이 바르지 않고 요철이 있는 상태였다. 수술 후 54 개월 뒤 추적 관 찰에서, 손톱은 완전히 자라 반대 측 소지의 손톱과 동일한 모양을 보 였다. 이는 Zook's criteria 상 excellent에 해당하였다[2]. 환자는 일상 생활에서 전혀 불편함을 느끼지 않았다. 공여부인 동측 족부의 무지 에서는 약간의 내향성 발톱이 확인되었으나 통증은 없었고, 일상생 활에 지장을 주지는 않았다(Fig. 3).

\section{증례 2}

24세 남성 환자는 프레스에 수상하여 좌측 무지의 압궤 손상으로 내원하였다. 원위지골의 골절은 없었으나 무균 기질의 $1.0 \times 1.0 \mathrm{~cm}^{2}$ 의 결손이 있었고, 원위지골이 $1 \mathrm{~cm}$ 가량 노출되었다. 증례 1 과 동일한 방 식으로 동측족부의 무지에서 결손 부위에 맞게 무균 기질을 떼어내 어 방향에 맞게 결손부에 봉합하였고, 분리된 손톱과 함께 봉합 고정 드레싱(tie-over dressing)을 시행하였다. 수술 후 18개월 뒤 추적 관찰 에서 반대측 손톱과 차이를 보이지 않았고, 공여부 또한 약간의 내향 성 발톱이 생긴 것 외에는 특이 문제가 없었다(Fig. 4).

\section{고 찰}

조갑상 손상에 있어 치료법은 다양한 방법이 소개되고 있으나 하나 의 이상적인 치료법으로 아직 정리되지는 않았다. 비교적 작은 크기 의 결손에서는 무균 기질을 피판화시킨 뒤 전진시켜 결손 부위를 피 복할 수 있고, 절단된 끝을 다듬어 단단성형술을 시행할 수도 있으며,
이식술을 시행할 수도 있다. 만약 조갑상의 결손이 큰 경우, 복합조갑 이식술이나, 발톱 전체를 포함한 유리 피판술을 시행할 수 있으나 이 는 동측 발톱 전체를 희생하여야 하는 단점이 있다[3-5].

손톱의 특성상 배아 기질(germinal matrix)이 손톱 성장의 $90 \%$ 를 담당하며, 무기 기질(sterile matrix)은 손톱의 바로 아래층에서 손톱 이 바닥과 부착되게 할 수 있는 얇은 세포층이다[6-9]. 이러한 무기 기 질의 특성을 무시한 채, 단순히 피부 이식술만을 결손부에 시행한 경 우, 배아 기질에서 자란 손톱이 이식된 피부 위로 부착이 되지 않고 뜬 상태로 자라게 되어 환자에게 심한 불편감을 초래하게 된다[10,11].

조갑상의 결손과 함께 원위지골의 노출이 발생하면, 조갑상 이식 편의 생착을 위한 혈류가 소실되어 생착이 어렵다. 조갑상과 원위지 골은 밀접하게 붙어있어 손톱의 손상이 있는 수지 첨부의 연부 조직 결손에서는 원위지골의 노출이 비교적 흔하다. 이러한 노출된 원위 지골의 건조로 혈액 순환이 손상되고, 손상된 조갑상은 주위 조직과 함께 이차 유합되며 조갑의 변성을 일으킨다. 그러므로 일반적으로 원위지골의 노출이 포함된 조갑상의 결손에서는 골의 노출을 피복하 기 위해 피판술을 시행하게 되며, 저자에 따라서는 피판 위에 조갑상 이식을 권고하기도 한다[12,13].

그러나 본 연구에서는 원위지골의 노출이 있더라도 별도의 피판술 을 시행하지 않고 바로 노출된 원위지골 위에 조갑상 이식술을 시행 하였고, 이는 완전한 생착을 이루어 정상적인 손톱의 성장이 가능하 게 하였다. 이는 노출된 원위지골 주위의 상처 바닥의 혈류 공급이 원 활하였기에, 피부 이식의 생착 원리와 유사하게 이식편 주위로부터 혈관의 신형성이 이루어지며 생착된 것으로 추정된다.

비록 증례의 수가 많지는 않으나 본 연구에 따르면, 무균 기질의 손 상이 $1 \mathrm{~cm}^{2}$ 이하이며 골 노출이 $1 \mathrm{~cm}$ 이하의 작은 조갑상의 결손에서 는 노출된 원위지골 위로 직접적인 조갑상 이식술을 시행하더라도 성공적인 이식술이 될 수 있다고 생각된다. 
이해 관계

이 논문에는 이해 관계 충돌의 여지가 없음.

\section{ORCID iDs}

Jinha Park

https://orcid.org/0000-0003-3422-4662

Si Young Roh

https://orcid.org/0000-0002-8625-6124

\section{References}

1. Fiedler DK, Barrett JE, Lourie GM. Nail bed reconstruction using single-layer bovine acellular dermal matrix. J Hand Surg Am 2017;42:e67-74.

2. Zook EG, Guy RJ, Russell RC. A study of nail bed injuries: causes, treatment, and prognosis. J Hand Surg Am 1984;9: 247-52.

3. Sheehan JE. Replacement of thumb nail. JAMA 1929;92: 1253-5.

4. Lille S, Brown RE, Zook EE, et al. Free nonvascularized composite nail grafts: an institutional experience. Plast Reconstr Surg 2000;105:2412-5.

5. Endo T, Nakayama Y. Microtransfers for nail and fingertip replacement. Hand Clin 2002;18:615-22.

6. Lewis BL. Microscopic studies of fetal and mature nail and surrounding soft tissue. AMA Arch Derm Syphilol 1954; 70:733-47.

7. De Berker D, Mawhinney B, Sviland L. Quantification of regional matrix nail production. Br J Dermatol 1996;134: 1083-6.

8. Barron JN. The structure and function of the skin of the hand. Hand 1970;2:93-6.

9. Johnson M, Shuster S. Continuous formation of nail along the bed. Br J Dermatol 1993;128:277-80.

10. Brown RE, Zook EG, Russell RC. Fingertip reconstruction with flaps and nail bed grafts. J Hand Surg Am 1999;24:34551.

11. Shepard GH. Treatment of nail bed avulsions with splitthickness nail bed grafts. J Hand Surg Am 1983;8:49-54.

12. Lee KJ, Kim YW, Kim JS, et al. Nail bed defect reconstruction using a thenar fascial flap and subsequent nail bed grafting. Arch Plast Surg 2019;46:57-62.

13. Clayburgh RH, Wood MB, Cooney WP 3rd. Nail bed repair and reconstruction by reverse dermal grafts. J Hand Surg Am 1983;8(5 Pt 1):594-8. 